\title{
Design and validation of a nutritional recipe for a snack made of green banana peel flour (Musa paradisiaca)
}

\section{Desenho e validação de receita nutricional de "snack" feito com farinha de casca de banana verde (Musa paradisiaca)}

\author{
Camila Acosta-Coello ${ }^{1}$ Almendra Parodi-Redhead ${ }^{1}$, María Luisa Medina-Pizzali1* (i) \\ ${ }^{1}$ Universidad Peruana de Ciencias Aplicadas (UPC), Facultad de Ciencias de la Salud, Lima - Perú
}

${ }^{*}$ Corresponding Author: María Luisa Medina-Pizzali, Universidad Peruana de Ciencias Aplicadas (UPC), Facultad de Ciencias de la Salud, Carrera de Nutrición y Dietética, Av. Alameda San Marcos, Cuadra 2, Chorrillos, Lima 09 Perú, e-mail: pcnummed@upc.edu.pe

Cite as: Acosta-Coello, C., Parodi-Redhead, A., \& Medina-Pizzali, M. L. (2021). Design and validation of a nutritional recipe for a snack made of green banana peel flour (Musa paradisiaca). Brazilian Journal of Food Technology, 24, e2019349. https://doi.org/10.1590/1981-6723.34919

\begin{abstract}
This study aims to design and validate a nutritional recipe for a snack made of Green Banana (Musa paradisiaca) Peel Flour (GBPF) and to assess the nutritional composition and microbiological quality of the flour. Banana peel, a food industry by-product, is a nutritious, low-cost material available for all year. Banana peel flower could be used as a functional ingredient due to its high fiber content and good functional properties. In general, university students have a deficient dietary fiber intake due to altered dietary patterns; thus, this study was focused on this population. The GBPFs were obtained from the peels of pre-climacteric bananas by fluidized bed (FDB) dryer, after which, microbiological, proximate, and dietary fiber analyses were applied. It was designed the nutritional recipe for the snack taking into account the energy and dietary fiber nutritional requirements of the target population. It could be validated and adjusted the recipe following the methodology of Centro Nacional de Alimentación y Nutrición, concluding with the determination of dietary fiber in the end-product. The dietary fiber, total carbohydrate, protein, total fat and energy contents of the GBPF were as following: $38.7 \mathrm{~g}, 76.3 \mathrm{~g}, 5.9 \mathrm{~g}, 3.6 \mathrm{~g}$, and $361.2 \mathrm{kcal}$, per $100 \mathrm{~g}$ of flour. The snack contained $7.74 \mathrm{~g}$ of dietary fiber per serving size, having a good acceptance among the university students' panelists based on an organoleptic test. In conclusion, the GBPF showed great potential as a source of dietary fiber, and it was an excellent source of carbohydrates and other nutrients to a lesser degree. When included as a functional ingredient in the nutritional formulation of a snack, it had an overall positive effect on the product's organoleptic characteristics.
\end{abstract}

Keywords: Dietary fiber; Nutritional composition; Proximate analysis; Nutritious recipe; Functional ingredient; Dietary patterns.

\section{Resumo}

Este estudo tem como objetivo projetar e validar uma receita nutricional para um "snack" feito com farinha de casca de banana verde (Musa paradisiaca), além de avaliar a composição nutricional e a qualidade microbiológica da 
farinha. A casca de banana, um subproduto da indústria de alimentos, é um material nutritivo e de baixo custo, disponível durante todo o ano. A casca de banana pode ser usada como ingrediente funcional devido ao seu alto teor de fibras e às boas propriedades funcionais. Em geral, os estudantes universitários têm uma ingestão deficiente de fibras alimentares devido a padrões alimentares alterados; assim, esse estudo focou nessa população. A farinha de casca de banana verde foi obtida a partir das cascas de bananas pré-climatéricas por secagem em leito fluidizado; em seguida foram realizadas análises microbiológicas, de composição centesimal e de fibras alimentares. Criou-se a receita nutricional para o "snack", levando-se em consideração as necessidades nutricionais de energia e fibras alimentares da população-alvo. A receita foi validada e ajustada seguindo a metodologia do Centro Nacional de Alimentación y Nutrición, concluindo com a determinação da fibra alimentar no produto final. Os teores de fibra alimentar, carboidrato total, proteína, gordura total e energia da farinha de casca banana verde foram, respectivamente: $38,7 \mathrm{~g}, 76,3 \mathrm{~g}, 5,9 \mathrm{~g}, 3,6 \mathrm{~g}$ e 361,2 kcal, por $100 \mathrm{~g}$ de farinha. O "snack" continha 7,74 g de fibra alimentar por porção, tendo uma boa aceitação entre os participantes universitários, com base em um teste organoléptico. Em conclusão, a farinha de casca de banana verde mostrou grande potencial como fonte de fibra alimentar, sendo uma excelente fonte de carboidratos e, em menor grau, de outros nutrientes. Quando incluída como ingrediente funcional na formulação nutricional de um lanche, teve um efeito geral positivo nas características organolépticas do produto.

Palavras-chave: Fibra alimentar; Composição nutricional; Análise aproximada; Receita nutricional; Ingrediente funcional; Padrões alimentares.

\section{Introduction}

Dietary fiber consumption provides a wide range of health benefits (Anderson et al., 2009; Fuller et al., 2016). Dietary fiber should be studied, taking into account its different components to understand its clinical benefits, however, most epidemiological evidence comes from the study of fiber in the whole food (Fuller et al., 2016; Huang et al., 2015). In a large prospective study in the United States of America (USA), the consumption of dietary fiber was identified as a protective factor for risk of total or cause-specific death due to various chronic diseases such as cancer, cardiovascular diseases, diabetes mellitus, among others (Huang et al., 2015). The reason for this, it is that high fiber intake improves serum lipoprotein values, reduces blood pressure, aids weight reduction, and promotes regularity (Anderson et al., 2009). There is evidence showing that soluble fibers play a part in blood glucose attenuation, cholesterol reduction, and insoluble fibers promoting laxation (Fuller et al., 2016). Besides, prebiotic fibers have a beneficial effect on the intestinal flora, which in turn has a direct effect on gut function, improving host nutrition and immunity (Gong \& Yang, 2012).

Current lifestyles have influenced the consumption of a diet based on fresh and minimally processed foods, towards a diet favoring highly processed foods. Owing to issues of convenience and accessibility, ultraprocessed foods have gained popularity in recent years. Most foods in this category are high in healthsensitive nutrients such as fat, simple sugars, and sodium, in addition to being densely energetic (Monteiro et al., 2010). Therefore, their consumption can contribute to gut microbiota and nutritional imbalances (Aguayo-Patrón \& Calderón de la Barca, 2017). The intake of refined-flour bakery products does not provide a sufficient amount of dietary fiber to consumers (U.S. Food and Drug Administration, 2018), and in some countries, consumers still prefer products made with refined grains to whole grain products. However, the overall trend worldwide is a higher demand and consumption of high-fiber bakery products (Parantez Media, 2018).

For young people, the college period constitutes a moment of taking responsibility for their diet and food intake. Several studies highlight the college population as a vulnerable group from the nutritional point of view, since it is usually characterized by the predilection for fast food, sugary drinks, skipping main meals and snacking between meals. The diet of college students is usually rich in saturated fats and simple sugars, and it is deficient in dietary fiber (Costa Silva Zemdegs et al., 2011; Durán Agüero et al., 2012; Durán et al., 
2009). Likewise, the average fiber intake of the Peruvian population is not known. However, in the Latin American Study of Nutrition and Health (in Spanish Estudio Lationoamericano de Nutrición y Salud (ELANS)), it is noted that the intake of rice, pasta, and bread represents $35.8 \%$ of the total energy intake of a Peruvian urban area resident and from that percentage, only $2.07 \%$ corresponds to the consumption of whole-grain products (Kovalskys et al., 2018). In the USA, the average intake of dietary fiber is $16 \mathrm{~g} /$ day (Lanza et al., 1987), which is well below the recommended daily intake for this nutrient for Americans (25$30 \mathrm{~g}$ per day), (U.S. Food and Drug Administration, 2018) making low dietary fiber consumption a worrying issue, (Lanza et al., 1987). As a result of this, the importance of good eating habits developed in this particular life stage is evident (Del Río et al., 2016).

Recovering fruit and vegetable waste into the food supply enhances the sustainability of the food system. The transformation of horticultural waste into value-added ingredients and food products could lead to better human nutrition and food security (Augustin et al., 2020). The residues and food waste generated in vast quantities by food processing plants contain substantial amounts of dietary fiber, even more than the edible portion. Therefore, the dietary fiber obtained from food by-products can play a significant role as a highquality, functional ingredient (Goni \& Hervert-Hernandez, 2011), considering there is a growing interest in the health benefits of a wide range of bioactive ingredients (Weaver, 2014). In this sense, it is necessary to carry out studies focusing on the utilization of these by-products to develop value-added ingredients, according to the research by Alarcon-Garcia et al. (2013) who assessed the functionality of banana waste as a food ingredient. Moreover, the addition of banana peel flour to the composition of food products does not negatively affect organoleptic attributes such as texture, taste, and smell (Eshak, 2016), and it is a low-cost material, rich in insoluble dietary fiber (Angelis-Pereira et al., 2016). On the other hand, the banana peel is a good source of potassium, phosphorus, calcium, magnesium, and manganese (Angelis-Pereira et al., 2016; Eshak, 2016) polyunsaturated acids and essential amino acids (Happi Emaga et al., 2007) vitamins such as ascorbic acid, riboflavin, niacin, and folic acid as well as phenolic compounds (Arun et al., 2015). Despite not being used as food for human consumption directly, once processed can be used as a partial substitute for wheat flour in sausages (Rosero Chasoy \& Serna Cock, 2017), bread (Eshak, 2016), cookies (Arun et al., 2015) and pasta (Castelo-Branco et al., 2017). In a study carried out in Mexico, the composition and physicochemical properties of Green Banana Peel Flour (GBPF) were analyzed. They concluded that, in addition to its high dietary fiber content (mainly insoluble fiber), this flour has a high content of polyphenols and tannins, and a high capacity of water and oil retention, hence showing potential for use in the development of functional foods (Agama-Acevedo et al., 2016).

In Peru, the term plantain refers to the unripe or ripe banana fruit of any edible variety or genotype. Banana (Musa paradisiaca) is a tropical fruit, and its seasonality is throughout the year. The edible portion is equivalent to 66 grams per 100 grams of product, so the residue has a considerable weight (Cárdenas Diaz, 2009). According to the Ministry of Agriculture and Irrigation in Peru, the banana production for the year 2017, was 582, 7 thousand tons. The Peruvian departments with the highest banana production were Piura, Loreto, San Martín, Huánuco, and Ucayali (Ministerio de Agricultura y Riego, 2018).

Given the potential of green banana peel, this paper aimed to design and validate a nutritional recipe for a snack made of GBPF, as well as assessing the nutritional composition and microbiological quality of the flour.

\section{Material and methods}

The protocol to the Ethics and Research Committee of the Faculty of Health Sciences at Universidad Peruana de Ciencias Aplicadas in Lima (Peru) was submitted. They exempted the protocol from further revision and approved its execution based on the documents FCS/194-09-18 and FCS/CE 045-03-20. 
$105 \mathrm{~kg}$ banana sample were obtained from a primary wholesale fruit market located in Santa Anita, in Lima, Peru, from February to March 2019. Given the source of the sample, it could not be verified the banana species. The study had the following steps:

\subsection{Production of GBPF}

Fruits with two days of post-harvest time according to its maturity index (pre-climacteric) were selected, excluding damaged or contaminated fruit. Then, the fruits were transported to the Instituto de Desarrollo Agroindustrial de la Universidad Nacional Agraria La Molina (INNDA), where the fruit was weighed and kept in frozen storage for ten days. After that, it was defrosted, washed and disinfected in a stainless-steel vat with $0.2 \%$ PerActive solution (dilution of commercial $15 \%$ peracetic acid solution); then the peels were cut into small pieces on a stainless steel surface, and placed in a fluidized bed (FDB) dryer, for 6 hours at $70{ }^{\circ} \mathrm{C}$. Once dried, the material was finely ground using a hammer mill and sieved through a 212- $\mu \mathrm{m}$ sieve (Standard Mesh $\mathrm{N}^{\circ} 70$ ), and the \% humidity was determined. The GBPF was irradiated (radioisotope used Co ${ }^{60}$; emission: gamma rays; minimum absorbed dose: $8 \mathrm{kGy}$ ) to meet the microbiological quality national standards (Dirección General de Salud Ambiental, 2008), and stored in PEHD bags. The flour yields for each unit operation were calculated by dividing the amount of output produced by the amount of input used and expressed the results as percentages. The flow diagram for the production of GBPF is shown in Figure 1.

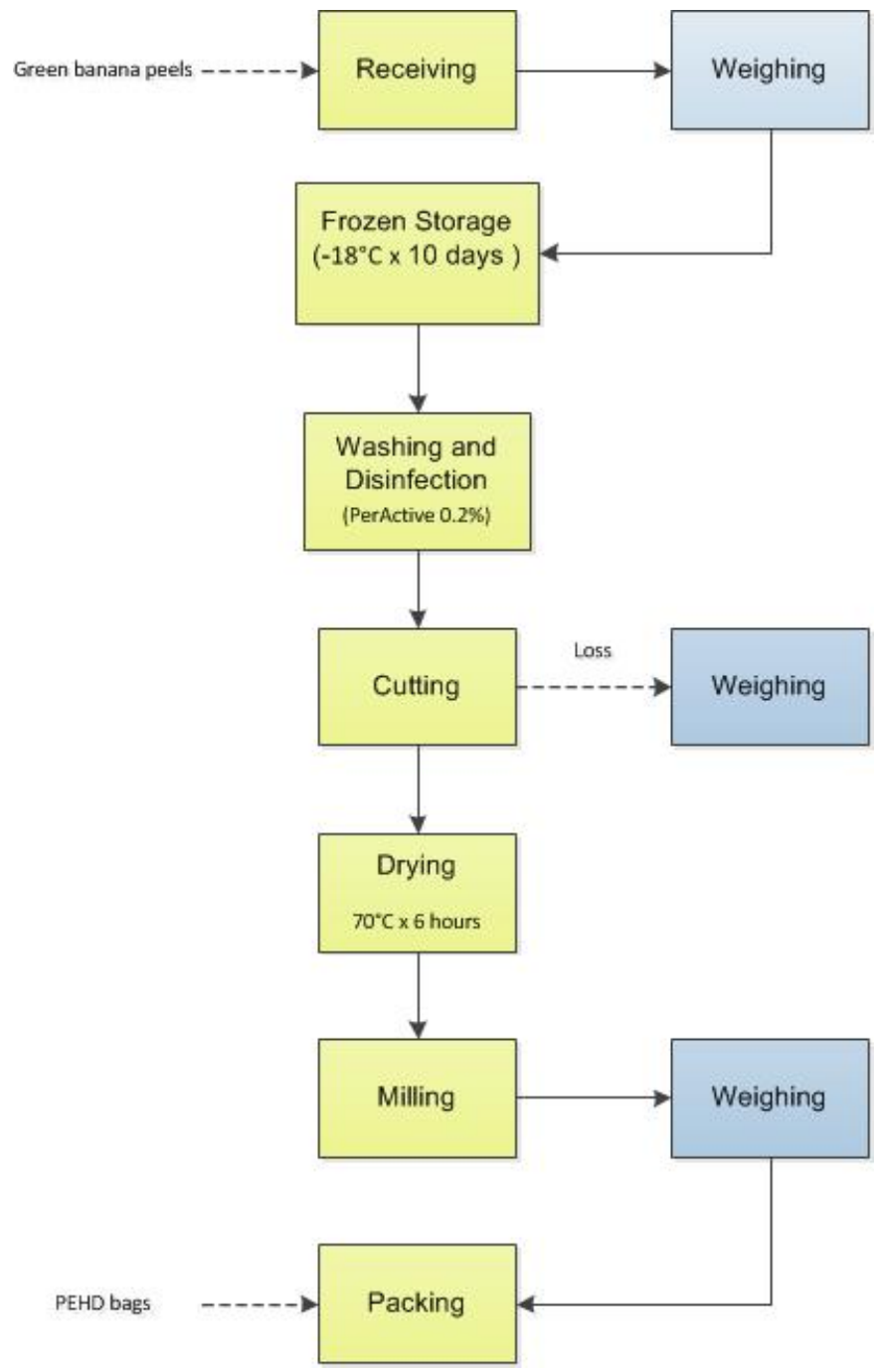

Figure 1. Flow diagram showing the operations for obtaining GBPF. 


\subsection{Characterization of the GBPF}

Indeed, $1 \mathrm{~kg}$ sample of GBPF was analyzed at La Molina Calidad Total Laboratorios (UNALM) to determine its physicochemical characteristics and microbiology quality. They quantified ash (AOAC 9030.05), moisture (AOAC 925.10), fat (AOAC 922.06), dietary fiber (AOAC 985.29), protein (AOAC 978.04 (A)) (AOAC International, 2016), and carbohydrates, and total energy content (Collazos et al., 1993). The carbohydrate content was calculated by difference, and it included the dietary fiber content. $4 \mathrm{kcal} / \mathrm{g}$ of carbohydrate were chosen for the calculation of the energy content. On the other hand, the microbiological quality relied on the determination of aerobic mesophiles, coliform bacteria, fungi and yeasts, Salmonella sp., E.coli, and Staphylococcus aureus (International Commission on Microbiological Specifications for Foods, 1983).

A single determination on the $1 \mathrm{~kg}$ sample for each of the above analyses was performed.

\subsection{Design, production, and validation of the nutritional recipe for the snack}

The recipe was designed by taking into account the energy and dietary fiber nutritional requirements of the target population: college students between aged from 18 to 25 years. The recommendations for energy intake requirements for the Peruvian population from Centro Nacional de Alimentación y Nutrición (CENAN) (Centro Nacional de Alimentación y Nutrición, 2012b), and the dietary fiber daily value from the Food and Drug Administration (FDA), USA (U.S. Food and Drug Administration, 2018) were used. The portion size of the snack was calculated, considering that it should not provide more than $10 \%$ of the daily energy requirement, according to the guidelines provided by Centro Nacional de Alimentación y Nutrición (2012b). The total nutritional contribution of the recipe using Peruvian nutritional tables as well as the results of the GBPF's proximal analysis were calculated, and then adjusted the formulation by changing the amount of GBPF to reach $5 \mathrm{~g}$ of dietary fiber per serving size. For the nutritional contribution of the GBPF, our calculations were based on the results of the proximal analysis and used the Tablas Peruanas de Composicion de Alimentos (Centro Nacional de Alimentación y Nutrición, 2009) for the remaining ingredients. The snack was produced in a batch process following the steps shown in Figure 2, according to the pilot nutritional recipe.

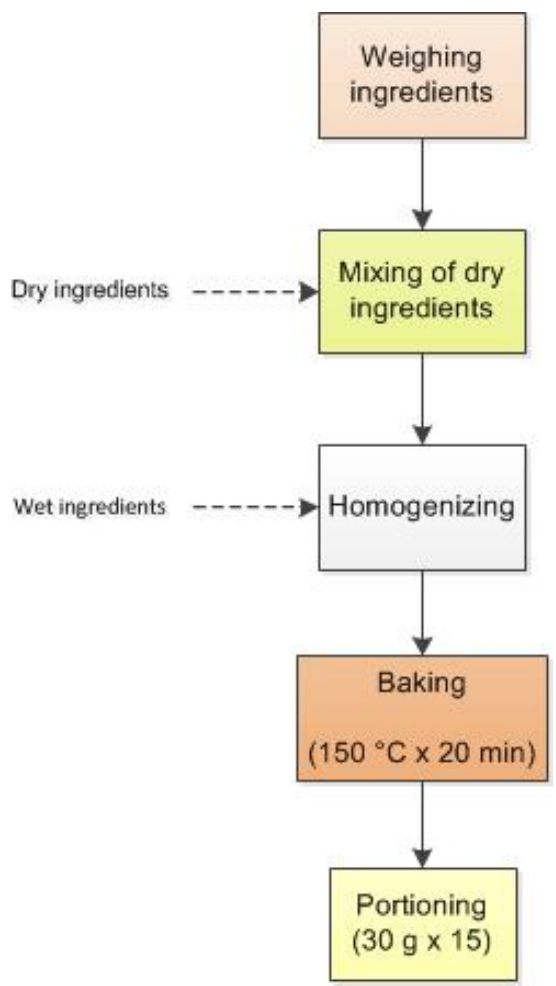

Figure 2. Flow diagram for the production of the snack with GBPF. 
The validation of the GBPF's pilot recipe was carried out through a panel composed of 20 college students of both gender (eleven men, nine women), enrolled at Universidad Peruana de Ciencias Aplicadas (UPC) at the time of the study, as approved by the Ethics and Research Committee of the Faculty of Health Sciences of the same institution. The panelists had similar socioeconomic characteristics, and those college students reporting allergies to any of the ingredients were excluded. A modified version of an instrument provided by CENAN was used (Figure 3), i.e., a questionnaire called Encuesta de opinion sobre recetas nutricionales (Centro Nacional de Alimentación y Nutrición, 2012a). The tasting panel carried out an organoleptic test to qualitatively assess the snack characteristics based on personal opinions and gave feedback, which was used to adjust the recipe and serving size. Once adjusted, the second validation of the recipe was performed, applying the same procedure.

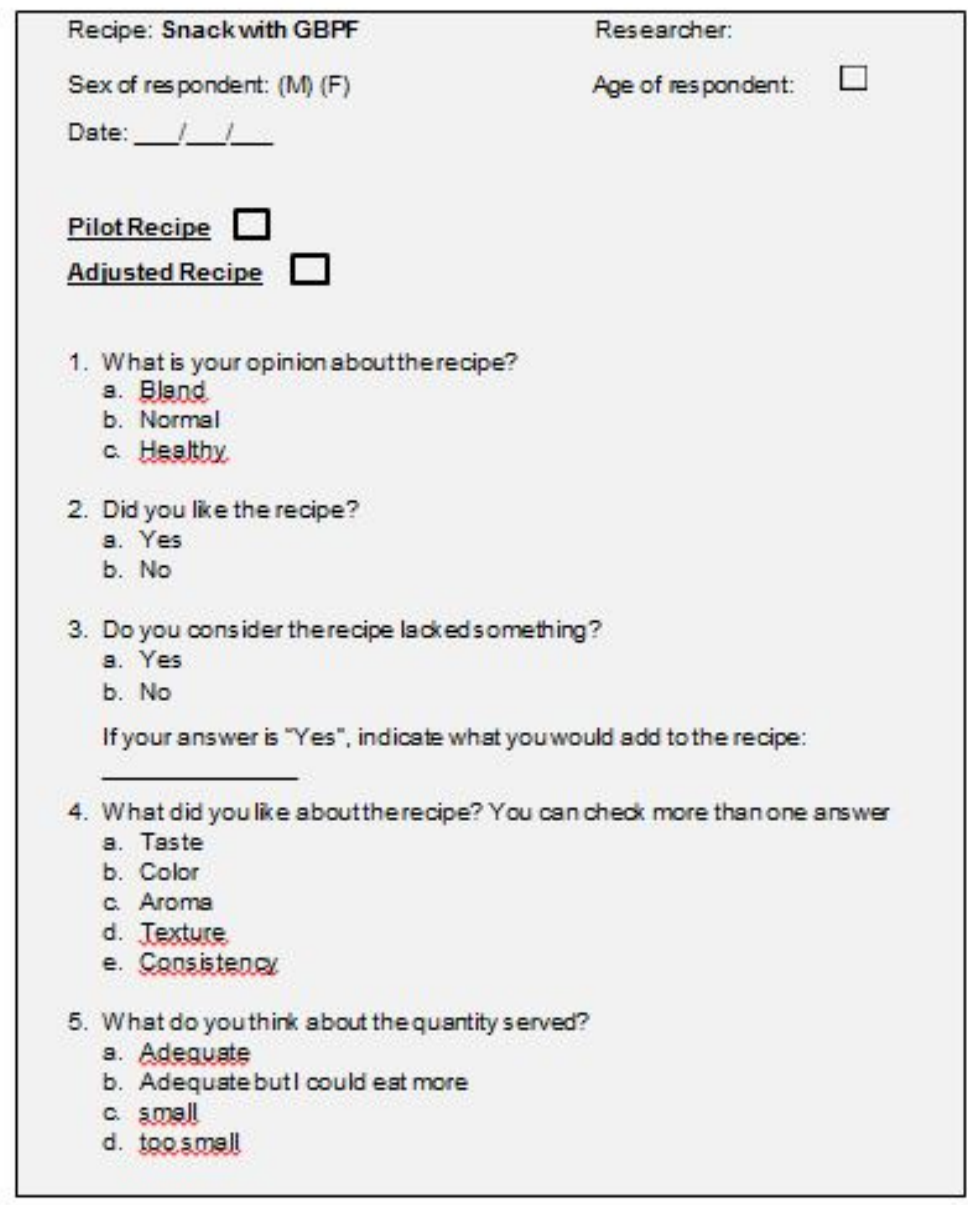

Figure 3. Questionnaire for panelists assessing the snack organoleptic characteristics.

\subsection{Final adjustment of the nutritional recipe for the snack}

The snack's recipe was adjusted for a second time in order to specify the ingredient quantities, the preparation procedure, and the dietary contribution per serving size $(30 \mathrm{~g})$.

\section{5 \%Dietary fiber determination in the snack made with the adjusted and validated nutritional recipe}

The snack was produced in a batch process and a sample was taken to UNALM to determine its $\%$ dietary fiber and verify the estimated contribution. 


\section{Results and discussion}

\subsection{Production of GBPF}

Table 1 shows the yields of the green banana peel until obtaining the GBPF. 36.84 kilograms of green banana peels with $83 \%$ moisture content were processed. Thus, $4.69 \mathrm{~kg}$ of GBPF with $2.85 \%$ moisture content could be obtained; the total yield being $12.73 \%$, accounted for losses during the drying, cutting, and grinding steps. In a study carried out with another species of banana and a different drying method, the yield of the GBPF was significantly lower, totaling 3.8\% (Castelo-Branco et al., 2017).

Table 1. GBPF yields per unitary operation.

\begin{tabular}{cccccc}
\hline \multirow{2}{*}{ Operation } & \multicolumn{3}{c}{ Material in process } & \multirow{2}{*}{ Loss (\%) } & \multirow{2}{*}{ Yield (\%) } \\
\cline { 2 - 5 } & $\begin{array}{c}\text { Input } \\
(\mathbf{k g})\end{array}$ & $\begin{array}{c}\text { Loss } \\
\mathbf{( k g )}\end{array}$ & $\begin{array}{c}\text { Output } \\
(\mathbf{k g})\end{array}$ & & \\
\hline Previous operations $^{\mathrm{a}}$ & 36.84 & 0 & 36.84 & 0 & 100 \\
\hline Cutting & 36.84 & 1.63 & 35.21 & 4.43 & 95.58 \\
\hline Drying & 35.21 & 30.34 & 4.87 & 86.17 & 13.83 \\
\hline Grinding & 4.87 & 0.18 & 4.69 & 3.70 & 96.30 \\
\hline Total & - & - & - & 87.27 & 12.73 \\
\hline
\end{tabular}

aPrevious technological operations = weighing, frozen storage, washing, and disinfection.

\subsection{Characterization of the GBPF}

Table 2 shows the physicochemical characterization of the GBPF according to the proximate analysis results.

Table 2. Proximate Analysis ${ }^{\mathrm{a}}$ : physicochemical characteristics of GBPF.

\begin{tabular}{cc}
\hline Physicochemical characteristic & Percentage Result \\
\hline Carbohydrates (g/100 g sample) & 76.3 \\
\hline Total Energy (kcal/100 g sample) & 361.2 \\
\hline \% kcal from carbohydrates & 84.5 \\
\hline$\%$ kcal from fat & 9.0 \\
\hline$\%$ kcal from protein & 6.5 \\
\hline Protein (g/100 g sample) (factor: 6.25) & 5.9 \\
\hline Fat (g/100 g sample) & 3.6 \\
\hline Moisture (g/100 g sample) & 4.6 \\
\hline Ash (g/100 g sample) & 9.6 \\
\hline Dietary fiber (g/100 g sample) & 38.7 \\
\hline
\end{tabular}

${ }^{\mathrm{a} A s}$ reported by La Molina Calidad Total Laboratorios - UNALM.

The difference between the moisture content determined after milling and the one obtained later in the proximate analysis was $1.75 \%$, and it is explained by water absorption from the environment (Food and Agriculture Organization of the United Nations, 2010) which occurred probably before packing the flour in bags and during its storage before the production of the snack.

Regarding protein, fat, and carbohydrates contents, the GBPF in our study presented $5.9 \mathrm{~g} / 100 \mathrm{~g}, 3.6 \mathrm{~g} / 100 \mathrm{~g}$, and $76.3 \mathrm{~g} / 100 \mathrm{~g}$, respectively. When comparing these results with those from research carried out in Malaysia with GBPF made from two different varieties of the same fruit, we could observe slightly lower values for protein and fat in the GBPF in our study, but a significantly higher value for carbohydrates (Ramli et al., 2010). In terms of dietary fiber, it could be obtained $38.7 \mathrm{~g} / 100 \mathrm{~g}$ of dietary fiber, which is lower compared to both varieties in the Malaysian study. The dietary fiber content for the "Cavendish" flour was $43.68 \mathrm{~g} / 100 \mathrm{~g}$, while for the second variety, "Dream Green", it was $42.65 \mathrm{~g} / 100 \mathrm{~g}$ of dietary fiber. Other studies have reported even higher values for dietary fiber content in GBPF, 
reaching 55.5\% (Lee et al., 2010). The differences may be explained by fruit variety and stage of maturation and other factors such as processing methods and parameters used (Ramli et al., 2010). The banana peels used for the elaboration of the flour in this study remained frozen for ten days before processing them, and the frozen storage could have affected the dietary fiber content due to degradation of the polysaccharides, as it was reported in other plant foods (Bouzari et al., 2015).

Table 3 shows the microbiological quality indicators in the flour. Compared to the Peruvian national standards (Dirección General de Salud Ambiental, 2008), our results indicated that the microbiological quality of the flour obtained was excellent, with minimal counts for all the indicator microorganisms required for the category of dehydrated fruits and vegetables.

Table 3. Microbiological quality indicators ${ }^{\mathrm{a}}$ in GBPF

\begin{tabular}{cccc}
\hline Indicator & \multirow{2}{*}{ Result } & \multicolumn{2}{c}{ Limit per gram } \\
\cline { 3 - 4 } & & m & M \\
\hline Yeast and Mold Count (UFC/g) ${ }^{\mathrm{b}}$ & $23 \times 10$ & $10^{2}$ & $10^{3}$ \\
\hline E.coli count $(\mathrm{MPN} / \mathrm{g}$ ) & $<3$ & 10 & $5 \times 10^{2}$ \\
\hline Staphylococcus Aureus count $(\mathrm{MPN} / \mathrm{g})^{\mathrm{d}}$ & $<3$ & 10 & $10^{2}$ \\
\hline Salmonella sp. count (in $25 \mathrm{~g}$ ) & Absence & Absence $/ 25 \mathrm{~g}$ \\
\hline
\end{tabular}

${ }^{\mathrm{a}}$ As reported by La Molina Calidad Total Laboratorios - UNALM. ${ }^{\mathrm{b} E s t i m a t e d ~ n u m b e r . ~}{ }^{\mathrm{c}}$ Peruvian national limit for dehydrated fruits and vegetables (Dirección General de Salud Ambiental, 2008). ${ }^{\mathrm{d}}$ This analysis is not required in dehydrated fruits and vegetables, but it is necessary for other categories of dehydrated products.

\subsection{Design, production, and validation of the nutritional recipe for a snack}

The maximum energy contribution of snacks was calculated based on $10 \%$ of the energy requirements for the average Peruvian adult men and women between 18 and 29 years of age, under normal health conditions, as shown in Table 4. The energy contribution of the snack was $108 \mathrm{kcal}$ per serving, representing $40 \%$ and $52 \%$ of the $10 \%$ daily energy requirement for men and women in this population segment, as shown in Table 5.

Table 4. Energy contribution of a snack according to the energy requirements of the target population according to gender.

\begin{tabular}{ccc}
\hline Population segment & CENAN $^{\text {a }}$ Energy requirement (kcal) & $\mathbf{1 0 \%}^{\text {10 daily requirement (kcal) }}$ \\
\hline 18 a 29 years-old men & 2689 & 269 \\
\hline 18 a 29 years-old women & 2045 & 205 \\
\hline${ }^{\mathrm{a}}$ Centro Nacional de Alimentación y Nutrición $(2012 \mathrm{~b})$ & &
\end{tabular}

${ }^{a}$ Centro Nacional de Alimentación y Nutrición (2012b).

Table 5. Formulation of a snack according to physicochemical characteristics of the GBPFa

\begin{tabular}{|c|c|c|c|c|c|c|c|}
\hline Ingredient & Volume measure ${ }^{b}$ & Weight (g) & $\begin{array}{c}\text { Energy } \\
\text { (kcal) }\end{array}$ & Protein $(g)$ & Fat (g) & Carbohydrates (g) & $\begin{array}{l}\text { Dietary } \\
\text { fiber }(\mathrm{g})\end{array}$ \\
\hline GBPF & $1 \frac{1}{2}$ cup & 187.5 & 667.3 & 11.1 & 16.9 & 143.1 & 72.6 \\
\hline $\begin{array}{l}\text { Wheat flour, } \\
\text { fortified } \mathrm{w} \text { / iron }\end{array}$ & $1 / 2$ cup & 62.5 & 226.3 & 6.6 & 1.3 & 47.7 & 1.7 \\
\hline Butter w/ salt & $3 / 4$ cup & 170 & 1218.9 & 1.5 & 137.9 & 0.2 & 0.0 \\
\hline Water & $1 / 2$ cup & 125 & 0 & 0 & 0 & 0 & 0 \\
\hline Salt & $1 \mathrm{tsp}$ & 3 & 0 & 0 & 0 & 0 & 0 \\
\hline Spices & $1 \mathrm{tsp}$ & 3 & 0 & 0 & 0 & 0 & 0 \\
\hline \multicolumn{2}{|c|}{ TOTAL } & 483 & 1620.5 & 18.5 & 99.2 & 190.9 & 74.3 \\
\hline Servings & Weight/serving & 32.2 & 108 & 1.2 & 6.6 & 12.7 & 5 \\
\hline
\end{tabular}

${ }^{a}$ The nutritional values of the remaining food ingredients were obtained from Tablas Peruanas de Composicion de Alimentos (Centro Nacional de Alimentación y Nutrición, 2009). ${ }^{\mathrm{b}} 1$ Cup of flour $=125 \mathrm{~g}, 1$ cup of water $=250 \mathrm{~g}, 1$ cup of butter $=100 \mathrm{~g}, 1$ teaspoon $=3 \mathrm{~g}$.

The snack was immediately tested by the tasting panel after producing it according to the pilot recipe, following the Procedimiento para el diseño y Validación de recetas nutricionales (Centro Nacional de Alimentación y Nutrición, 2012a). Based on this methodology, panelists belonging to the target population 
gave their opinions about the product characteristics, which were taken into account to adjust the formulation without the use of statistical analysis of the data. Thus, $75 \%$ of the panelists agreed that the snack was bland; when asked what they would add to the recipe to make it tastier, 55\% stated they would add spices (such as rosemary or oregano), $25 \%$ said the product needed more salt while $20 \%$ said they would add chocolate chips. The GBPF had a dark brown color due to the oxidation of the peels during processing, imparting a dark color to the snack; however, $75 \%$ of the panelists liked the color. A study in India (Arun et al., 2015), reported similar results in cookies produced with partial substitution of wheat flour by banana peel flour, the color was darker due to the presence of pigments present naturally in the peels such as polyphenols and chlorophylls. Additionally, in our study, $100 \%$ of the panelists liked the texture of the snack; they mentioned that it had a better texture compared to commercially produced cookies. Arun et al. (2015) observed that the hardness of their product decreased significantly while more banana peel flour was added to the formulation, they explained this effect by the decrease of net gluten formation and the higher water retention. Likewise, Rosero Chasoy \& Serna Cock (2017) showed that banana peel flour could be used as a substitute for synthetic binders and extenders when making frankfurter sausages, demonstrating that banana peel flour could replace up to $25 \%$ of wheat flour in the sausage formulation, without affecting emulsifying stability, or $\mathrm{pH}$, and favoring water retention capacity.

Finally, $90 \%$ of the panelists deemed the serving size as adequate; meanwhile, the remaining $10 \%$ stated that the serving size should be $50 \%$ larger.

For the adjustment of the nutritional recipe, we increased the amount of spices added to the snack. The panelists assessed the adjusted version of the snack again, and as a result, we obtained a final $85 \%$ acceptance of the snack produced according to the modified recipe.

\subsection{Final adjustment of the nutritional recipe for the snack}

Based on the second feedback of the panelists, the final adjustment of the nutritional recipe for the snack was made, and we wrote the recipe, including the following information:

- Title: Snack with green banana peel flour;

- Ingredients: Green banana peel flour, wheat flour, butter with salt, water, salt, various spices (rosemary, oregano);

- Preparation: according to flow-diagram;

- Number of portions: 15 (30 g each);

- Estimated contribution of dietary fiber per serving: $5 \mathrm{~g}$;

- Nutritional message of the recipe: "Our snack is a product made with Green Banana Peel Flour (GBPF), and it is an excellent source of fiber."

\section{5 \% Dietary fiber determination in the snack made with the adjusted and validated nutritional recipe}

The confirmatory result of the determination of \% dietary fiber in the snack produced, according to the adjusted and validated recipe, was $25.8 \mathrm{~g} / 100 \mathrm{~g}$ sample, which is equivalent to $7.74 \mathrm{~g}$ per serving $(30 \mathrm{~g})$. This value exceeded the estimated dietary content according to our calculations. Considering the dietary fiber content of the wheat flour was obtained from the Tablas Peruanas de Composición de Alimentos (Centro Nacional de Alimentación y Nutrición, 2009), which reports average values, we should expect some variation when using a specific brand. On the other hand, the FDA's recommended dietary fiber daily value ranges between 25 to 30 per day for a 2000 to 2500 calorie diet (U.S. Food and Drug Administration, 2018). In that sense, the FDA has approved claims based on the daily value percentage of this nutrient in products. If a product provides between $10 \%$ to $19 \%$ of the daily value of dietary fiber $(2.5$ to $5.7 \mathrm{~g}$ ), it can be recognized as a "good source of fiber", while if it exceeds $20 \%$ of the requirement ( $>5$ to $6 \mathrm{~g}$ ), the product is considered 
"high in fiber" or an "excellent source of fiber" (U.S. Food and Drug Administration, 2019). Thus, $7.74 \mathrm{~g}$ of dietary fiber per $30 \mathrm{~g}$ of snack makes this product an excellent source of dietary fiber.

\section{Limitations}

When characterizing the GBPF, the proximal and microbiological analysis in triplicate were not performed; thus, we cannot discuss the variability in our sample.

\section{Conclusions}

A nutritional recipe for a snack aimed at Peruvian college students could be designed and validated, using GBPF to reach a minimum dietary fiber level of $5 \mathrm{~g} / 100 \mathrm{~g}$ of product. Our findings indicate that the flour is a source of various nutrients, mainly carbohydrates, and can be used in the production of a baked nutritional product formulated to be an excellent source of fiber. According to a college student's tasting panel, GBPF had the advantage of having an overall positive effect on the organoleptic characteristics of the product. In conclusion, the GBPF showed great potential as a functional ingredient and can be included in nutritional recipes.

\section{References}

Agama-Acevedo, E., Sañudo-Barajas, J. A., Vélez De La Rocha, R., González-Aguilar, G. A., \& Bello-Peréz, L. A. (2016). Potential of plantain peels flour (Musa paradisiaca L.) as a source of dietary fiber and antioxidant compound. CYTA: Journal of Food, 14(1), 117-123. http://dx.doi.org/10.1080/19476337.2015.1055306

Aguayo-Patrón, S., \& Calderón de la Barca, A. (2017). Old fashioned vs. ultra-processed-based current diets: possible implication in the increased susceptibility to type 1 diabetes and celiac disease in childhood. Foods, 6(11), 100. PMid:29140275. http://dx.doi.org/10.3390/foods6110100

Alarcón García, M. Á., López Vargas, J. H., \& Restrepo Molina, D. A. (2013). Characterization of technological functionality of dietary fiber rich source obtained from plantain peel. Revista Facultad Nacional de Agronomía, 66(1), 6959-6968. Retrieved in 2019, December 26, from http://www.scielo.org.co/scielo.php?script=sci_arttext\&pid=S030428472013000100013\&lng=en\&nrm=iso\&tlng=es

Anderson, J. W., Baird, P., Davis Junior, R. H., Ferreri, S., Knudtson, M., Koraym, A., Waters, V., \& Williams, C. L. (2009). Health benefits of dietary fiber. Nutrition Reviews, 67(4), 188-205. PMid:19335713. http://dx.doi.org/10.1111/j.17534887.2009.00189.x

Angelis-Pereira, M. C., Barcelos, M., Pereira, R. C., Pereira, J. A. R., \& de Sousa, R. V. (2016). Chemical composition of unripe banana peels and pulps flours and its effects on blood glucose of rats. Nutrition \& Food Science, 46(4), 504-516. http://dx.doi.org/10.1108/NFS-11-2015-0150

AOAC International (2016). Official Methods of Analysis (OMA) (20th ed.). Gaithersburg: AOAC International.

Arun, K. B., Persia, F., Aswathy, P. S., Chandran, J., Sajeev, M. S., Jayamurthy, P., \& Nisha, P. (2015). Plantain peel: A potential source of antioxidant dietary fibre for developing functional cookies. Journal of Food Science and Technology, 52(10), 6355-6364. PMid:26396380. http://dx.doi.org/10.1007/s13197-015-1727-1

Augustin, M. A., Sanguansri, L., Fox, E. M., Cobiac, L., \& Cole, M. B. (2020). Recovery of wasted fruit and vegetables for improving sustainable diets. Trends in Food Science \& Technology, 95, 75-85. http://dx.doi.org/10.1016/j.tifs.2019.11.010

Bouzari, A., Holstege, D., \& Barrett, D. M. (2015). Mineral, fiber, and total phenolic retention in eight fruits and vegetables: A comparison of refrigerated and frozen storage. Journal of Agricultural and Food Chemistry, 63(3), 951-956. PMid:25525668. http://dx.doi.org/10.1021/jf504890k

Cárdenas Diaz, F. (2009). Estudio del Mercado de la Cadena de Plátano (Informe final de consultoría). Peru: Dirección de Promoción de Competitividad Agraria. Retrieved in 2019, December 26, from http://agroaldia.minagri.gob.pe/biblioteca/download/pdf/manuales-boletines/banano/estudio_platano.pdf

Castelo-Branco, V. N., Guimarães, J. N., Souza, L., Guedes, M. R., Silva, P. M., Ferrão, L. L., Miyahira, R. F., Guimarães, R. R., Freitas, S. M. L., Reis, M. C., \& Zago, L. (2017). Uso da farinha de polpa e de casca de banana verde (Musa balbisiana) como ingrediente para a elaboração de massa tipo talharim. Brazilian Journal of Food Technology, 20, e2016119. https://doi.org/http://dx.doi.org/10.1590/1981-6723.11916

Centro Nacional de Alimentación y Nutrición - CENAN. (2009). Tablas peruanas de composición de alimentos Ministerio de Salud República del Perú (p. 50). Lima. Retrieved in 2019, December 26, from http://www.ins.gob.pe/insvirtual/images/otrpubs/pdf/Tabla de Alimentos.pdf

Centro Nacional de Alimentación y Nutrición - CENAN. (2012a). Procedimiento para el diseño y validacion de recetas nutricionales (p. 32). Lima. Retrieved in 2019, December 26, from 
https://web.ins.gob.pe/sites/default/files/Archivos/cenan/deprydan/documentosNormativos/6_Procedimiento de diseño de recetas.pdf

Centro Nacional de Alimentación y Nutrición - CENAN. (2012b). Requerimientos de energía para la población peruana. Lima. Retrieved in 2019, December 26, from

https://web.ins.gob.pe/sites/default/files/Archivos/cenan/deprydan/lamejorreceta/Requerimiento de energía para la población peruana.pdf

Collazos, C., White, P. L., Viñas, E., Alvistur, E., Urquieta, R., \& Vasquez, J. (1993). Composición de los alimentos de mayor consumo en el Peru (6. ed.). Lima: Ministerio de Salud, Instituto Nacional de Nutrición.

Costa Silva Zemdegs, J., Barreto Corsi, L., De Castro Coelho, L., Duarte Pimentel, G., Toyomi Hirai, A., \& Sachs, A. (2011). Perfil lipídico y factores de riesgo cardiovascular en estudiantes universitarios brasileños de primer ano de sao paulo. Nutrición Hospitalaria, 26(3), 553-559. PMid:21892574. http://dx.doi.org/10.3305/nh.2011.26.3.4660

Del Río, M. P. R., Silleras, B. D. M., Enciso, L. C., De Miguelsanz, J. M. M., McPhee, M. F., \& Martín, M. A. C. (2016). Ingesta dietética y adherencia a la dieta mediterránea en un grupo de estudiantes universitarios en función de la práctica deportiva. Nutrición Hospitalaria, 33(5), 1172-1178. http://dx.doi.org/10.20960/nh.583

Dirección General de Salud Ambiental. (2008). Norma sanitaria que establece los criterios microbiologicos de calidad sanitaria e inocuidad para los alimentos y bebidas de consumo humano. Perú.

Durán Agüero, S., Bazaez Díaz, G., Figueroa Velásquez, K., del Berlanga Zúñiga, M. R., Encina Vega, C., \& del Rodríguez Noel, M. P. (2012). Comparación en calidad de vida y estado nutricional entre alumnus de nutrición y dietética y de otras carreras universitarias de la universidad Santo Tomás de Chile. Nutrición Hospitalaria, 27(3), 739-746. PMid:23114938. http://dx.doi.org/10.3305/nh.2012.27.3.5746

Durán, S., Castillo, M., \& Vio del R, F. (2009). Diferencias en la calidad de vida de estudiantes universitarios de diferente año de ingreso del Campus Antumapu. Revista Chilena de Nutrición, 36(3), 200-209. http://dx.doi.org/10.4067/S071775182009000300002

Eshak, N. S. (2016). Sensory evaluation and nutritional value of balady flat bread supplemented with banana peels as a natural source of dietary fiber. Annals of Agricultural Science, 61(2), 229-235. http://dx.doi.org/10.1016/j.aoas.2016.07.002

Food and Agriculture Organization of the United Nations - FAO. (2010). Dried fruit: fruit processing toolkit. Rome. https://doi.org/10.1017/S002081830000607X

Fuller, S., Beck, E., Salman, H., \& Tapsell, L. (2016). New horizons for the study of dietary fiber and health: A review. Plant Foods for Human Nutrition, 71(1), 1-12. PMid:26847187. http://dx.doi.org/10.1007/s11130-016-0529-6

Gong, J., \& Yang, C. (2012). Advances in the methods for studying gut microbiota and their relevance to the research of dietary fiber functions. Food Research International, 48(2), 916-929. http://dx.doi.org/10.1016/j.foodres.2011.12.027

Goni, I., \& Hervert-Hernandez, D. (2011). By-products from plant foods are sources of dietary fibre and antioxidants. In I. Rasooli (Ed.), Phytochemicals: Bioactivities and Impact on Health. http://dx.doi.org/10.5772/27923

Happi Emaga, T., Andrianaivo, R. H., Wathelet, B., Tchango, J. T., \& Paquot, M. (2007). Effects of the stage of maturation and varieties on the chemical composition of banana and plantain peels. Food Chemistry, 103(2), 590-600. http://dx.doi.org/10.1016/j.foodchem.2006.09.006

Huang, T., Xu, M., Lee, A., Cho, S., \& Qi, L. (2015). Consumption of whole grains and cereal fiber and total and cause-specific mortality: prospective analysis of 367,442 individuals. BMC Medicine, 13(1), 59. PMid:25858689. http://dx.doi.org/10.1186/s12916-015-0294-7

International Commission on Microbiological Specifications for Foods - ICMSF. (1983). Microorganismos de los alimentos (2. ed., Vol. 1, Técnicas de análisis microbiológico). Zaragoza: Editorial Acribia.

Kovalskys, I., Fisberg, M., Gómez, G., Pareja, R. G., Yépez García, M. C., Cortés Sanabria, L. Y., Herrera-Cuenca, M., Rigotti, A., Guajardo, V., Zalcman Zimberg, I., Nogueira Previdelli, A., Moreno, L. A., \& Koletzko, B. (2018). Energy intake and food sources of eight Latin American countries: Results from the Latin American Study of Nutrition and Health (ELANS). Public Health Nutrition, 21(14), 2535-2547. PMid:29848396. http://dx.doi.org/10.1017/S1368980018001222

Lanza, E., Jones, D. Y., Block, G., \& Kessler, L. (1987). Dietary fiber intake in the US population. The American Journal of Clinical Nutrition, 46(5), 790-797. http://dx.doi.org/10.1093/ajcn/46.5.790

Lee, E. H., Yeom, H. J., Ha, M. S., \& Bae, D. H. (2010). Development of banana peel jelly and its antioxidant and textural properties. Food Science and Biotechnology, 19(2), 449-455. http://dx.doi.org/10.1007/s10068-010-0063-5

Ministerio de Agricultura y Riego. (2018). Boletin Estadistico de Produccion Agricola y Ganadera, IV trimestre 2017. Retrieved in 2019, December 26, from http://www.minagri.gob.pe/portal/download/pdf/herramientas/boletines/prod-agricolaganadera/prod-agricola-ganadera-iv-trimestre2017_020318.pdf

Monteiro, C. A., Levy, R. B., Claro, R. M., Castro, I. R. R., \& Cannon, G. (2010). A new classification of foods based on the extent and purpose of their processing. Cadernos de Saude Publica, 26(11), 2039-2049. PMid:21180977. http://dx.doi.org/10.1590/S0102-311X2010001100005

Parantez Media. (2018). World bread market and trends. BBM Magazine. Retrieved in 2019, December 26, from http://www.magazinebbm.com/english/world-bread-market-and-trends/.html

Ramli, S., Ismail, N., Alkarkhi, A. F. M., \& Easa, A. M. (2010). The use of principal component and cluster analysis to differentiate banana peel flours based on their starch and dietary fibre components. Tropical Life Sciences Research, 21(1), 91 100. PMid:24575193. 
Design and validation of a nutritional recipe for a snack made of green banana peel flour (Musa paradisiaca)

Acosta-Coello, C. et al.

Rosero Chasoy, G., \& Serna Cock, L. (2017). Effect of plantain (Musa paradisiaca L. cv. Dominico Harton) peel flour as binder in frankfurter-type sausage. Acta Agronomica, 66(3), 305-310. http://dx.doi.org/10.15446/acag.v66n3.56695

U.S. Food and Drug Administration (2018). Nutrition facts label, dietary fiber (pp. 1-2). Silver Spring. Retrieved in 2019,

December 26, from https://www.accessdata.fda.gov/scripts/interactivenutritionfactslabel/dietary-fiber.html

U.S. Food and Drug Administration. (2019). CFR - Code of Federal Regulations Title 21. Silver Spring.

Weaver, C. M. (2014). Bioactive foods and ingredients for health. Advances in Nutrition, 5(3), 306S-311S. PMid:24829482.

http://dx.doi.org/10.3945/an.113.005124

Funding: This study was carried out with the financial support of

Dirección de Investigación de la Universidad Peruana de Ciencias Aplicadas (B-034-2019).

Received: Dec. 26, 2019; Accepted: Sept. 17, 2020 